\title{
Water Pollution and Its Causes in the Tuojiang River Basin, China: An Artificial Neural Network Analysis
}

\author{
Zheng Zeng $\mathbb{D}$, Wei-Ge Luo $\mathbb{1}$, Zhe Wang and Fa-Cheng Yi * \\ College of Environment and Resources, Southwest University of Science and Technology, \\ Mianyang 621010, China; zengzheng@vip.163.com (Z.Z.); comeluoweige@163.com (W.-G.L.); \\ wz2004@126.com (Z.W.) \\ * Correspondence: yfc66@163.com
}

check for

updates

Citation: Zeng, Z.; Luo, W.-G.; Wang,

Z.; Yi, F.-C. Water Pollution and Its Causes in the Tuojiang River Basin, China: An Artificial Neural Network Analysis. Sustainability 2021, 13, 792. https:/ / doi.org/10.3390/su13020792

Received: 16 December 2020 Accepted: 13 January 2021

Published: 15 January 2021

Publisher's Note: MDPI stays neutral with regard to jurisdictional clai$\mathrm{ms}$ in published maps and institutional affiliations.

Copyright: () 2021 by the authors. Licensee MDPI, Basel, Switzerland. This article is an open access article distributed under the terms and conditions of the Creative Commons Attribution (CC BY) license (https:// creativecommons.org/licenses/by/ $4.0 /)$.

\begin{abstract}
This work aimed to assess the water quality of the Tuojiang River Basin in recent years to provide a better understanding of its current pollution situation, and the potential pollution risks and causes. Water quality parameters such as dissolved oxygen (DO), ammonia-nitrogen $\left(\mathrm{NH}_{3}-\mathrm{N}\right)$, total phosphorus (TP), the permanganate index (CODMn), five-day biochemical oxygen demand (BOD5), $\mathrm{pH}$, and concentrations of various heavy metals were measured in the Tuojiang River, according to the national standards of the People's Republic of China. Samples were collected between 2012 to 2018 at 11 national monitoring sites in the Tuojiang River Basin. The overall water pollution situation was evaluated with back propagation artificial neural network (BP-ANN) analysis. The pollution causes were analyzed considering both industrial wastewater discharge in the upper reaches and the current pollution situation. We found potential risks of excessive $\mathrm{NH}_{3}-\mathrm{N}, \mathrm{TP}, \mathrm{Cd}, \mathrm{Hg}$, and $\mathrm{Pb}$ concentrations in the Tuojiang River Basin. Moreover, corresponding water pollution control suggestions were given.
\end{abstract}

Keywords: Tuojiang River; water pollution; heavy metal pollution; BP-ANN evaluation

\section{Introduction}

With the rapid urban and industrial development, water pollution has gradually become a serious issue [1-5]. Many water-related diseases such as Minamata disease and bone pain disease have emerged together with other water pollutants, causing severe harm to human life and health [6]. Generally, water pollution can be classified as organic matter pollution [7], excessive nutrients, mainly nitrogen and phosphorus [8,9], and heavy metal pollution. In particular, the rapid economic development in Southwest China has led to a series of imbalances between the natural environment and industrial development [10]. According to the Environment Bulletin of Sichuan Province in 2019 [11], there are issues of excessive cadmium, lead, and mercury in the Tuojiang River Basin. The conflict between water resource conservation and industrial development in the Tuojiang River Basin is a typical contradiction between human beings and nature. To control the problems and risks associated with excess heavy metals in the Tuojiang River Basin, it is necessary to understand the pollution causes and potential risks to the Tuojiang River Basin's water resources.

Environmental pollution can be identified from environmental variables using single factor and multi-factor analysis methods. A representative of the single-factor method is the Nemerow pollution index [12]. However, single-factor analyses are associated with many problems, mainly because they conduct an isolated evaluation of various impact factors, which may not accurately represent a comprehensive, multiple-stressor water quality situation [13]. Multi-factor analysis methods include the fuzzy analysis method [14-18], the grey system analysis method [19], the hierarchical analysis method [20], the ecological footprint method [21], and the artificial neural network (ANN) analysis method [22]. Multi-factor analyses can provide comprehensive water quality information by assigning 
weights to influencing factors, overcoming the limitations of single-factor methods [23]. Multi-factor analyses have other advantages. For example, ecological footprint analysis can correlate water quality with the potential environmental risks posed by the social and economic development of surrounding areas, which could contribute to assessing the whole environment's carrying capacity. ANN, for example, has a variety of ductility functions including simulation prediction and nonlinear evaluation.

ANN originated in the 1980s and can be described as a large-scale nonlinear system connected by a large number of artificial neurons [24]. ANN is a physical abstraction, simplification, and simulation of the human brain. ANN possesses the unique characteristics and capacities of strong parallel processing, nonlinear mapping, self-organization, self-learning, adaptive function, error tolerance, and robustness [25]. The structure of ANN is divided into an input layer, hidden layer, and output layer. The input layer comprises the neurons receiving external stimulation, while the hidden layer comprises the neurons processing the information. The output layer is the neurons' feedback to the external world. The functions between neurons connect each layer of the ANN. ANN has two working modes (i.e., autonomous learning and calculation).

However, the determination of the number of hidden layers and its neurons are a complicated problem [26]. The more complex the computational model, the more hidden layers are required. The number of hidden layers depends on the prediction purpose. Namely, the number of hidden layers can be specified, but its neurons are uncertain. The small number of hidden neurons would cause output that may not meet the desired requirements, and too large a number would cause a long training and calculation time. Generally, there are rules of thumb to help researchers determine the number of hidden neurons $[27,28]$. Empirical rules emphasize the relationship between the number of hidden neurons and the number of neurons in the three layers, and based on this, many scholars have come up with their own methods of determining the hidden neurons [27,29-33]. In this paper, we used the empirical formula (number of inputs + outputs) $*(1 / 2)$ [34] to determine the hidden neurons.

Substitute: At present, there are nearly 40 kinds of neural network models including back-propagation network (BP-ANN), multilayer perceptron (MLP), self-organizing mapping (SOM), Hopfield network (HN), Boltzmann machine (BM), adaptive resonance theory (ART), and so on. MLP and SOM convert data of any dimension into one or two dimensional discrete maps, so that they are suitable for multilayer image perception classification. $\mathrm{HN}$ is a recursive ANN and suitable for natural language processing. BM and ART are advanced ANN, which are designed specifically for energy computing and autonomic environment interaction. According to the different applications of these ANN models, finally, we chose BP-ANN as our prediction model.

$\mathrm{BP}-\mathrm{ANN}$ is one of the most widely used ANN, and BP refers to the ANN's self-learning mode. The BP self-learning process comprises two major processes: forward propagation of signals and backward propagation of errors. In forward propagation, sample information passes from the input layer to the hidden layer and the output layer. If the output layer's actual output data does not match the expected output, the error back-propagation phase will be turned on. The process of signal forward and backward propagation leads to a constant adjustment of the parameters and weights of the internal layer functions. The whole process could be regarded as the ANN self-learning process. When the errors of self-learning reach the preset allowable value, the ANN can make a prediction.

ANN has been widely used in water quality analysis and the industry due to its excellent self-learning ability. Wang et al. [35] used BP-ANN to evaluate the Daqing River's water quality in Liaoning Province, China. Zhao et al. [36] successfully predicted and estimated the Minjiang River estuary's water quality using BP-ANN. Ghiassi et al. [37] used dynamic ANN to predict urban water consumption. Alvisi et al. [38] used ANN to predict the variations of river water level, and Firat et al. [39] established an ANN for urban water consumption prediction. As a reliable ANN with a simple structure, BP-ANN 
can learn autonomously, reduce the error, and make the output accurate and idealized. Therefore, BP-ANN has become a hot topic in many research fields.

This paper aimed to use BP-ANN to comprehensively analyze the water quality in the Tuojiang River Basin. The temporal and spatial analysis of the measured variables and the output data of the BP-ANN were used to assess the overall pollution situation and to identify the pollution index that represents the greatest impact on the environment. By analyzing the factors of wastewater discharge in the upper reaches of the river and phosphorus pollution by industrial and mining operations, the river's self-purification, and seasonal variation in pollutants in the Tuojiang River Basin, this paper assessed the pollution causes in this basin in the last ten years. This paper's results and conclusions may be useful for the strategic planning of water resource utilization and ecologicalenvironmental development for the cities and counties in the Chengdu Plain in the future.

\section{Materials and Methods}

\subsection{Data Acquisition}

Water quality data were collected from 11 sampling sites along the Tuojiang River (Figure 1). These sites were all national first-class water quality monitoring sites. The sites were densely distributed in the upper and lower reaches of the river, but sparse in the middle reaches. The sections between the Jinghu and Shiqiao sites in the upper reaches belong to Deyang and Chengdu's municipalities urban divisions and are characterized by substantial domestic sewage and industrial wastewater inputs. The sections from Chengdu to Ziyang are characterized by rural land use, with very few villages. The water quality in these sections is relatively stable, so fewer sampling sites have been established in the middle reaches. The sections from Neijiang to Luzhou in the lower reaches, where the Tuojiang River is about to converge with the Yangtze River, are densely populated. The pollutant loads of Tuojiang River represent a significant impact on the water quality of the Yangtze River.

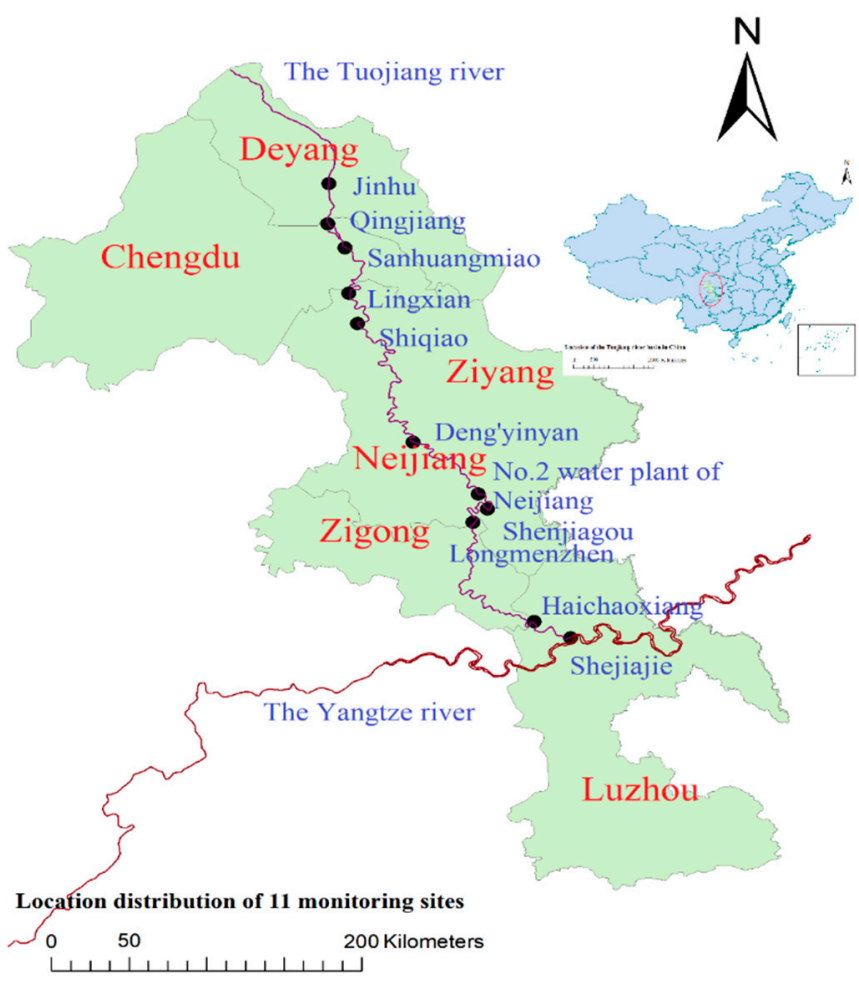

Figure 1. The distribution of the 11 sampling sites along the Tuojiang River. Monitoring sites are in blue, municipalities in red.

Sites were sampled monthly between January 2012 and December 2018. The main monitoring variables included $\mathrm{pH}$, dissolved oxygen (DO), ammonia-nitrogen $\left(\mathrm{NH}_{3}-\mathrm{N}\right)$, 
total phosphorus (TP), five-day biochemical oxygen demand $\left(\mathrm{BOD}_{5}\right)$, the permanganate index for chemical oxygen demand (CODMn) as well as copper, zinc, arsenic, cadmium, hexavalent chromium, mercury, and lead. Sampling sections were selected to avoid local pollution sources and other factors that could cause water pollution spikes. The sampling process was in strict accordance with the surface water-related monitoring technical specifications and national standard methods. The water samples were quickly brought back to the laboratory for analysis and determination within $24 \mathrm{~h}$ after sampling.

\subsection{Back Propagation (BP) Artificial Neural Network Analysis}

In previous water quality assessments using BP-ANN in Chinese rivers, the concentration limits of the five water quality classes of the Chinese national surface water environmental quality standard were used as the input eigenvalues for sample learning. A disadvantage of this approach is that the upper limit of water quality class I was used as an evaluation standard, and therefore could not accurately represent water quality better than class I. Thus, the lower limits of class I were added to the learning process to solve this problem. The evaluation sample dataset is shown in Table 1. A BP-ANN model with 12 input nodes, six hidden layers, and one output node was then established in the MATLAB software (version 2016a) (Figure 2). The random assignment of initial learning parameters, initial weights, and thresholds was carried out using the rand function, and water quality standards (Table 1) were used as learning samples. The learning time was set to $10^{5}$, while the error limit was $10^{-8}$.
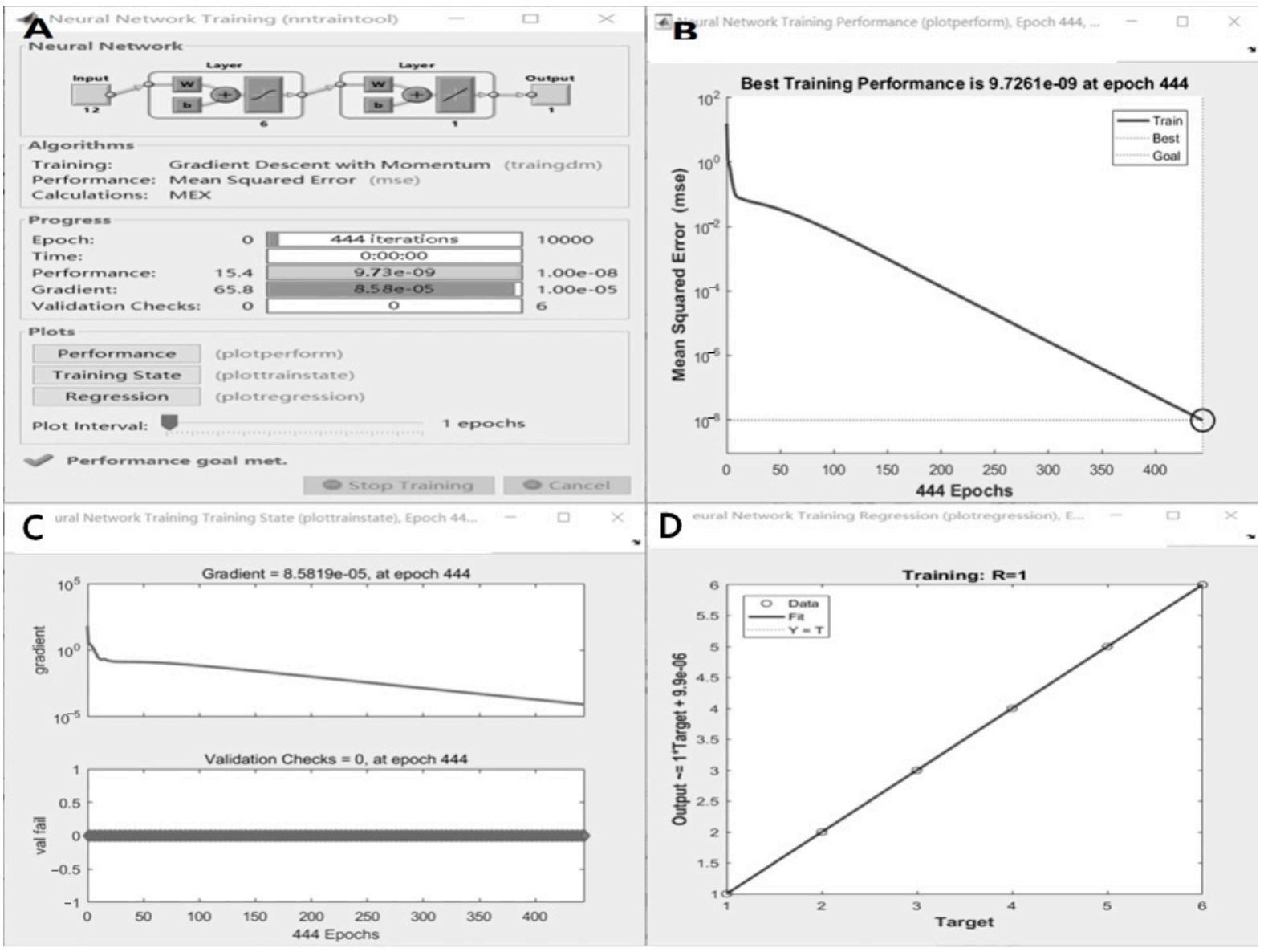

Figure 2. Results of self-learning of the back propagation-artificial neural network (BP-ANN) and the parameters for the self-learning process. (A) shows the structure of the ANN model and its calculation progress. (B) shows its training performance, and pattern convergence (i.e., successful ANN self-training). (C) shows the validation check, also proving the successful self-training. (D) shows the output with an R value of 1 , showing that the ANN model is ready to work. 
Table 1. Learning samples and the expected output results. Unit: $\mathrm{mg} \cdot \mathrm{L}^{-1}$.

\begin{tabular}{|c|c|c|c|c|c|c|c|c|c|c|c|c|c|}
\hline Water Quality Levels & DO & $\mathrm{COD}_{\mathrm{Mn}}$ & BOD $_{5}$ & $\mathrm{NH}_{3}-\mathrm{N}$ & TP & $\mathrm{Cu}$ & $\mathrm{Zn}$ & As & $\mathrm{Hg}$ & $\mathrm{Cd}$ & $\mathrm{Cr}$ & $\mathbf{P b}$ & $\begin{array}{l}\text { Expected Output } \\
\text { Results }\end{array}$ \\
\hline Lower limit of class I & 10 & 0 & 0 & 0 & 0 & 0 & 0 & 0 & 0 & 0 & 0 & 0 & 1.0 \\
\hline Upper limit of class I & 7.5 & 2 & 3 & 0.15 & 0.02 & 0.01 & 0.05 & 0.05 & 0.00005 & 0.001 & 0.01 & 0.01 & 2.0 \\
\hline Upper limit of class III & 5 & 6 & 4 & 1.5 & 0.2 & 1.0 & 1.0 & 0.05 & 0.0001 & 0.005 & 0.05 & 0.05 & 4.0 \\
\hline Upper limit of class IV & 3 & 10 & 6 & 2.0 & 0.3 & 1.0 & 2.0 & 0.1 & 0.001 & 0.005 & 0.05 & 0.05 & 5.0 \\
\hline Upper limit of class $\mathrm{V}$ & 2 & 15 & 10 & 4.0 & 0.4 & 1.0 & 2.0 & 0.1 & 0.001 & 0.01 & 0.1 & 0.1 & 6.0 \\
\hline
\end{tabular}


After 444 learning and training cycles, the accuracy requirement of e $<10^{-8}$ was reached with a total time consumption of less than $1 \mathrm{~s} \mathrm{(Figure} \mathrm{2A).} \mathrm{Other} \mathrm{training} \mathrm{parame-}$ ters are shown in Figure 2B-D. The trained sample output is shown in Table 2.

Table 2. Comparison between the output data of sample learning and the expected output results.

\begin{tabular}{cccc}
\hline Water Quality Levels & $\begin{array}{c}\text { Expected } \\
\text { Output Results }\end{array}$ & $\begin{array}{c}\text { Output Data of Sample } \\
\text { Learning }\end{array}$ & Relative Error \\
\hline Lower limit of class I & 1.0 & 1.0000 & 0 \\
Upper limit of class I & 2.0 & 1.9999 & $0.005 \%$ \\
Upper limit of class II & 3.0 & 3.0001 & $0.0033 \%$ \\
Upper limit of class III & 4.0 & 3.9999 & $0.0025 \%$ \\
Upper limit of class IV & 5.0 & 5.0002 & $0.004 \%$ \\
Upper limit of class V & 6.0 & 5.9999 & $0.0017 \%$ \\
\hline
\end{tabular}

After learning and training, the BP-ANN analyzed the annual average variation and the average value of each monitoring site using the data from the 11 monitoring sites from 2012 to 2018. The comprehensive water quality analysis results are shown in Tables 3 and 4 .

Table 3. The input data of BP-ANN (Time order). Unit: $\mathrm{mg} \cdot \mathrm{L}^{-1}$.

\begin{tabular}{|c|c|c|c|c|c|c|c|c|c|c|c|c|}
\hline & DO & $\mathrm{COD}_{\mathrm{MN}}$ & BOD $_{5}$ & $\mathrm{NH}_{3}-\mathrm{N}$ & TP & $\mathrm{Cu}$ & $\mathrm{Zn}$ & As & $\mathrm{Hg}$ & Cd & $\mathrm{Cr}$ & $\mathrm{Pb}$ \\
\hline 2018 & 7.201508 & 2.876508 & 2.219857 & 0.303779 & 0.158150 & 0.006332 & 0.014854 & 0.001629 & 0.000034 & 0.003316 & 0.007847 & 0.013664 \\
\hline 2017 & & & 2.262879 & & & & & & & & & \\
\hline 2016 & 6.521894 & 2.973674 & 2.298864 & & 69 & & & & & & & \\
\hline 2015 & 6.512109 & & & & 0.22 & & & & 0.000 & 0.0 & 0.00 & 0.016395 \\
\hline 2014 & 6.346293 & 3.644210 & 2.753193 & & 0.220915 & 0.005705 & 0.022908 & 0.002527 & 0.000022 & 0.004103 & 0.004 & 0.016821 \\
\hline 2013 & 6.226625 & 4.281488 & 3.315565 & 0.671824 & 0.212715 & 0.006188 & 0.018706 & 0.002081 & 0.000023 & 0.004102 & 0.005179 & 0.017153 \\
\hline 2012 & 6.278375 & 4.318871 & 3.009394 & 0.628209 & 0.222948 & 0.004874 & 0.016742 & 0.001323 & 0.000023 & 0.004103 & 0.004840 & 0.017111 \\
\hline
\end{tabular}

Table 4. The input data of BP-ANN (Location order). Unit: $\mathrm{mg} \cdot \mathrm{L}^{-1}$.

\begin{tabular}{lcccccccccccc}
\hline & $\mathbf{D O}$ & $\mathbf{C O D}_{\mathbf{M N}}$ & BOD $_{\mathbf{5}}$ & $\mathbf{N H}_{\mathbf{3}} \mathbf{- N}$ & $\mathbf{T P}$ & $\mathbf{C u}$ & $\mathbf{Z n}$ & $\mathbf{A s}$ & $\mathbf{H g}$ & $\mathbf{C d}$ & $\mathbf{C r}$ & $\mathbf{P b}$ \\
\hline A & 8.3333 & 2.744048 & 3.84833 & 0.492688 & 0.052446 & 0.002084 & 0.010807 & 0.002 & 0.000072 & 0.000061 & 0.004433 & 0.001909 \\
B & 7.99049 & 3.437596 & 3.470539 & 0.732768 & 0.2374 & 0.002384 & 0.01487 & 0.002652 & 0.000072 & 0.000063 & 0.005389 & 0.001296 \\
C & 7.37587 & 3.400092 & 3.820971 & 1.623636 & 0.248205 & 0.00347 & 0.026678 & 0.002608 & 0.000073 & 0.000062 & 0.00524 & 0.002247 \\
D & 6.38924 & 3.536447 & 2.41804 & 0.650549 & 0.236923 & 0.004637 & 0.016474 & 0.001682 & 0.000029 & 0.003589 & 0.004 & 0.014383 \\
E & 7.37587 & 3.400092 & 3.820971 & 1.623636 & 0.248205 & 0.00347 & 0.026678 & 0.002608 & 0.000073 & 0.000062 & 0.00524 & 0.002247 \\
F & 6.115934 & 3.353571 & 2.34185 & 0.369863 & 0.218141 & 0.005856 & 0.017962 & 0.001453 & 0.000013 & 0.005000 & 0.005369 & 0.02 \\
G & 6.09359 & 3.336172 & 2.382234 & 0.289588 & 0.219542 & 0.00544 & 0.017098 & 0.001559 & 0.000015 & 0.005000 & 0.0055 & 0.02 \\
H & 6.044505 & 3.50696 & 2.429121 & 0.427436 & 0.233159 & 0.00519 & 0.018141 & 0.001702 & 0.000012 & 0.005000 & 0.005048 & 0.02 \\
I & 6.508929 & 3.247024 & 2.306548 & 0.306226 & 0.153155 & 0.008345 & 0.015643 & 0.001217 & 0.000014 & 0.005000 & 0.004571 & 0.02 \\
J & 6.030476 & 3.827279 & 2.440136 & 0.333735 & 0.206299 & 0.00519 & 0.01416 & 0.00187 & 0.000015 & 0.005000 & 0.005238 & 0.02 \\
K & 5.949908 & 3.859432 & 2.466392 & 0.600531 & 0.232289 & 0.006488 & 0.018535 & 0.002014 & 0.000015 & 0.005000 & 0.005 & 0.02 \\
\hline
\end{tabular}

\section{Results and Discussion}

3.1. Results

Sensitivity Analysis

According to Tables 3 and 4, we obtained Tables 5 and 6 by means of BP-ANN. In order to figure out which independent variables involved in the BP-ANN evaluation had a greater contribution to water quality, we adopted the network sensitivity analysis to achieve this goal. 
Table 5. Comprehensive water quality analysis of the Tuojiang River Basin between 2012 and 2018 based on BP-ANN.

\begin{tabular}{|c|c|c|c|c|c|c|c|c|c|c|c|c|c|c|c|}
\hline \multirow{2}{*}{ Year } & \multirow{2}{*}{$\begin{array}{c}\text { Aims of } \\
\text { Water Quality }\end{array}$} & \multicolumn{12}{|c|}{ Concentrations of Water Quality Variables $\left(\mathrm{mg} \cdot \mathrm{L}^{-1}\right)$} & \multirow{2}{*}{$\begin{array}{l}\text { Output } \\
\text { Results }\end{array}$} & \multirow{2}{*}{$\begin{array}{l}\text { Comprehensive } \\
\text { Water Quality }\end{array}$} \\
\hline & & DO & $\mathrm{COD}_{\mathrm{Mn}}$ & BOD $_{5}$ & $\mathrm{NH}_{3}-\mathrm{N}$ & TP & $\mathrm{Cu}$ & Zn & As & $\mathrm{Hg}$ & Cd & $\mathrm{Cr}$ & $\mathbf{P b}$ & & \\
\hline 2012 & III & 7.201508 & 2.876508 & 2.219857 & 0.303779 & 0.158150 & 0.006332 & 0.014854 & 0.001629 & 0.000034 & 0.003316 & 0.007847 & 0.013664 & 2.0104 & II \\
\hline 2013 & III & 6.931364 & 2.751894 & 2.262879 & 0.421424 & 0.227462 & 0.004431 & 0.013032 & 0.001498 & 0.000035 & 0.003316 & 0.005765 & 0.013405 & 2.0104 & II \\
\hline 2014 & III & 6.521894 & 2.973674 & 2.298864 & 0.547197 & 0.218769 & 0.004742 & 0.019881 & 0.001051 & 0.000027 & 0.004102 & 0.004275 & 0.016509 & 2.0082 & II \\
\hline 2015 & III & 6.512109 & 3.498793 & 2.545413 & 0.579236 & 0.226038 & 0.004664 & 0.019727 & 0.002253 & 0.000024 & 0.004103 & 0.004607 & 0.016395 & 2.0056 & II \\
\hline 2016 & III & 6.346293 & 3.644210 & 2.753193 & 0.706488 & 0.220915 & 0.005705 & 0.022908 & 0.002527 & 0.000022 & 0.004103 & 0.004672 & 0.016821 & 2.0032 & II \\
\hline 2017 & III & 6.226625 & 4.281488 & 3.315565 & 0.671824 & 0.212715 & 0.006188 & 0.018706 & 0.002081 & 0.000023 & 0.004102 & 0.005179 & 0.017153 & 2.0001 & II \\
\hline 2018 & III & 6.278375 & 4.318871 & 3.009394 & 0.628209 & 0.222948 & 0.004874 & 0.016742 & 0.001323 & 0.000023 & 0.004103 & 0.004840 & 0.017111 & 1.9973 & I \\
\hline
\end{tabular}

Table 6. Averaged water quality analysis of each monitoring site in the Tuojiang River Basin between 2012 and 2018 based on BP-ANN.

\begin{tabular}{|c|c|c|c|c|c|c|c|c|c|c|c|c|c|c|c|}
\hline \multirow{2}{*}{$\begin{array}{c}\text { Monitoring } \\
\text { Sites * }\end{array}$} & \multirow{2}{*}{$\begin{array}{c}\text { Aims of } \\
\text { Water Quality }\end{array}$} & \multicolumn{12}{|c|}{ Concentrations of Water Quality Variables $\left(\mathrm{mg} \cdot \mathrm{L}^{-1}\right)$} & \multirow{2}{*}{$\begin{array}{l}\text { Output } \\
\text { Results }\end{array}$} & \multirow{2}{*}{$\begin{array}{c}\text { Comprehensive } \\
\text { Water Quality }\end{array}$} \\
\hline & & DO & $\mathrm{COD}_{\mathrm{Mn}}$ & BOD $_{5}$ & $\mathrm{NH}_{3}-\mathrm{N}$ & TP & $\mathrm{Cu}$ & $\mathrm{Zn}$ & As & $\mathrm{Hg}$ & Cd & $\mathrm{Cr}$ & $\mathbf{P b}$ & & \\
\hline A & III & 8.3333 & 8.098929 & 2.744048 & 3.84833 & 0.492688 & 0.052446 & 0.002084 & 0.010807 & 0.002 & 0.000072 & 0.000061 & 0.004433 & 1.9934 & I \\
\hline $\mathrm{B}$ & III & 7.99049 & 7.929327 & 3.437596 & 3.470539 & 0.732768 & 0.2374 & 0.002384 & 0.01487 & 0.002652 & 0.000072 & 0.000063 & 0.005389 & 1.9983 & $\mathrm{I}$ \\
\hline $\mathrm{C}$ & III & 7.37587 & 7.745806 & 3.400092 & 3.820971 & 1.623636 & 0.248205 & 0.00347 & 0.026678 & 0.002608 & 0.000073 & 0.000062 & 0.00524 & 2.0082 & II \\
\hline $\mathrm{D}$ & III & 6.38924 & 7.957051 & 3.536447 & 2.41804 & 0.650549 & 0.236923 & 0.004637 & 0.016474 & 0.001682 & 0.000029 & 0.003589 & 0.004 & 2.0085 & II \\
\hline $\mathrm{E}$ & III & 7.37587 & 7.745806 & 3.400092 & 3.820971 & 1.623636 & 0.248205 & 0.00347 & 0.026678 & 0.002608 & 0.000073 & 0.000062 & 0.00524 & 2.0082 & II \\
\hline $\mathrm{F}$ & III & 6.115934 & 8.032042 & 3.353571 & 2.34185 & 0.369863 & 0.218141 & 0.005856 & 0.017962 & 0.001453 & 0.000013 & 0.005000 & 0.005369 & 2.0057 & II \\
\hline G & III & 6.09359 & 8.023333 & 3.336172 & 2.382234 & 0.289588 & 0.219542 & 0.00544 & 0.017098 & 0.001559 & 0.000015 & 0.005000 & 0.0055 & 2.0051 & II \\
\hline $\mathrm{H}$ & III & 6.044505 & 8.004093 & 3.50696 & 2.429121 & 0.427436 & 0.233159 & 0.00519 & 0.018141 & 0.001702 & 0.000012 & 0.005000 & 0.005048 & 2.0080 & II \\
\hline I & III & 6.508929 & 8.088393 & 3.247024 & 2.306548 & 0.306226 & 0.153155 & 0.008345 & 0.015643 & 0.001217 & 0.000014 & 0.005000 & 0.004571 & 2.0003 & II \\
\hline $\mathrm{J}$ & III & 6.030476 & 8.001578 & 3.827279 & 2.440136 & 0.333735 & 0.206299 & 0.00519 & 0.01416 & 0.00187 & 0.000015 & 0.005000 & 0.005238 & 2.0077 & II \\
\hline $\mathrm{K}$ & III & 5.949908 & 7.989396 & 3.859432 & 2.466392 & 0.600531 & 0.232289 & 0.006488 & 0.018535 & 0.002014 & 0.000015 & 0.005000 & 0.005 & 2.0132 & II \\
\hline
\end{tabular}

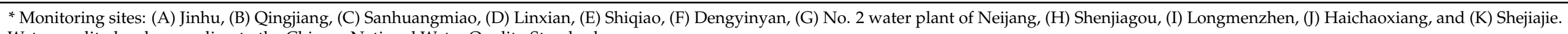
Water quality levels according to the Chinese National Water Quality Standard. 
Considering Table 5 (2012 to 2017 as the training sample and 2018 for sensitivity analysis) as an orthogonal test table, we obtained the preliminary sample data. The 12 independent variables involved are denoted as X1 to X12. Then, all preliminary data samples need to be normalized according to the formula below:

$$
\mathrm{Y}=0.1+0.8 \frac{\mathrm{X}-\mathrm{X}_{\min }}{\mathrm{X}_{\max }-\mathrm{X}_{\min }}
$$

$Y$ presents the data, which has been normalized. The normalized results are shown in Table 7 and the final sensitivity analysis results are shown in Table 8. According to Table 8, heavy metals have a significant impact on water quality, especially As and $\mathrm{Hg}$.

Table 7. Normalized results of the sensitivity analysis.

\begin{tabular}{cccccccccccc}
\hline Y1 & Y2 & Y3 & Y4 & Y5 & Y6 & Y7 & Y8 & Y9 & Y10 & Y11 & Y12 \\
\hline 0.9000 & 0.1636 & 0.1000 & 0.1000 & 0.1000 & 0.9000 & 0.2476 & 0.4847 & 0.8385 & 0.1000 & 0.9000 & 0.1553 \\
0.6783 & 0.1000 & 0.1314 & 0.3337 & 0.9000 & 0.1000 & 0.1000 & 0.3975 & 0.9000 & 0.1000 & 0.4337 & 0.1000 \\
0.3423 & 0.2132 & 0.1577 & 0.5836 & 0.7997 & 0.2309 & 0.6548 & 0.1000 & 0.4077 & 0.8990 & 0.1000 & 0.7625 \\
0.3343 & 0.4813 & 0.3377 & 0.6472 & 0.8836 & 0.1981 & 0.6423 & 0.9000 & 0.2231 & 0.9000 & 0.1744 & 0.7382 \\
0.1982 & 0.5556 & 0.4894 & 0.9000 & 0.8244 & 0.6361 & 0.9000 & 1.0824 & 0.1000 & 0.9000 & 0.1889 & 0.8291 \\
0.1000 & 0.8809 & 0.9000 & 0.8311 & 0.7298 & 0.8394 & 0.5596 & 0.7855 & 0.1615 & 0.8990 & 0.3025 & 0.9000 \\
0.1425 & 0.9000 & 0.6765 & 0.7445 & 0.8479 & 0.2864 & 0.4005 & 0.2810 & 0.1615 & 0.9000 & 0.2265 & 0.8910 \\
\hline
\end{tabular}

Table 8. The results of the sensitivity analysis.

\begin{tabular}{ccccccccccccc}
\hline $\begin{array}{c}\text { Independent } \\
\text { Variables }\end{array}$ & $\mathrm{DO}$ & $\mathrm{COD}_{\mathrm{MN}}$ & $\mathbf{B O D}_{5}$ & $\mathbf{N H}_{3}-\mathbf{N}$ & $\mathbf{T P}$ & $\mathbf{C u}$ & $\mathbf{Z n}$ & $\mathrm{As}$ & $\mathbf{H g}$ & $\mathbf{C d}$ & $\mathrm{Cr}$ & $\mathbf{P b}$ \\
\hline Sensitivity & 0.03666 & 0.01835 & 0.0733 & 0.0891 & 0.2673 & 0.0776 & 0.0701 & 0.8599 & 0.8135 & 0.4549 & 0.2549 & 0.2236 \\
\hline
\end{tabular}

\subsection{Discussion}

\subsubsection{Analysis of BP-ANN, Temporal, and Spatial Pollution Distribution}

According to Table 5, the comprehensive water quality score decreased from 2012 to 2018. By 2018, the average water quality score of the Tuojiang River Basin was less than 2, reaching class I. Compared with 2012, the comprehensive water quality score in 2018 was $0.65 \%$ lower, and the average annual water quality score was $0.093 \%$ lower. Table 6 shows that the water quality of monitoring sites A and B reached class I, while all other monitoring sites had class II. From the upper reaches, beginning at site A, to the lower reaches at site $\mathrm{K}$, the water quality score increased by $0.99 \%$, and the average water quality score of each monitoring site was $0.09 \%$ higher than that of the previous station. The water quality score of sites $B$ and $C$ increased most, indicating the most severe pollution $(0.5 \%)$. However, the water quality scores decreased from stations D to E, F to G, and H to I, which may be attributed to the improvement of water quality due to self-purification in the Tuojiang River Basin's middle reaches.

According to Table 9, each monitoring site's water quality scores decreased year by year. Most monitoring sites reached water quality class I in 2018, except for sites $\mathrm{H}$ and K. All the monitoring sites of Tuojiang River reached water quality class III. The water quality of monitoring site A always remained at class I, while site B's water quality assessment remained between 1.999 and 2.002. The water quality score of sites A and B in 2018 decreased by $0.02 \%$ and $0.2 \%$, respectively, compared with 2012 . Therefore, the water quality of monitoring sites A and B can be considered stable. Since 2012, the water quality score of sites C to K (excluding E) gradually decreased. By 2018 , the water quality scores of these sites had decreased by $0.86 \%$, $1.99 \%, 0.72 \%, 0.75 \%, 0.75 \%, 0.83 \%, 1.10 \%$, and $1.17 \%$. The water quality of site $\mathrm{E}$ increased initially and then decreased between 2012 and 2018. The value reached a maximum value in 2015 , and the final water quality score increased by $0.015 \%$. 
Table 9. Analysis of comprehensive water quality at each monitoring site from 2012 to 2018 using BP-ANN.

\begin{tabular}{cccccccc}
\hline Monitoring Sites & $\mathbf{2 0 1 2}$ & $\mathbf{2 0 1 3}$ & $\mathbf{2 0 1 4}$ & $\mathbf{2 0 1 5}$ & $\mathbf{2 0 1 6}$ & $\mathbf{2 0 1 7}$ & $\mathbf{2 0 1 8}$ \\
\hline A & 1.9920 & 1.9919 & 1.9918 & 1.9915 & 1.9907 & 1.9910 & 1.9916 \\
B & 1.9994 & 2.0025 & 2.006 & 1.9973 & 1.9964 & 1.9995 & 1.9954 \\
C & 2.015 & 2.0261 & 2.0206 & 2.0067 & 2.0055 & 2.0037 & 1.9977 \\
D & 2.0357 & 2.0284 & 2.0149 & 2.0098 & 2.0073 & 2.0007 & 1.9951 \\
E & 1.9937 & 1.9943 & 1.9984 & 2.0013 & 1.9990 & 1.9953 & 1.9940 \\
F & 2.0133 & 2.0132 & 2.0083 & 2.0091 & 2.0047 & 1.9999 & 1.9988 \\
G & 2.0147 & 2.0111 & 2.0079 & 2.0068 & 2.0028 & 1.9999 & 1.9996 \\
H & 2.0153 & 2.0144 & 2.0131 & 2.0095 & 2.0072 & 2.0029 & 2.0001 \\
I & 2.0114 & 2.0069 & 2.0035 & 1.9998 & 1.9985 & 1.9970 & 1.9948 \\
J & 2.0220 & 2.0164 & 2.0151 & 2.0078 & 2.0058 & 2.0001 & 1.9997 \\
K & 2.0248 & 2.0249 & 2.0150 & 2.157 & 2.0134 & 2.0084 & 2.0012 \\
\hline
\end{tabular}

According to Figure 3 , the average concentration of $\mathrm{DO}$ at the four monitoring sites $\mathrm{A}, \mathrm{B}, \mathrm{C}$, and $\mathrm{D}$ in the upper reaches remained stable at $8 \mathrm{mg} \cdot \mathrm{L}^{-1}$. In contrast, the DO concentrations in the lower reaches decreased gradually. The concentrations of stations $\mathrm{H}$, $\mathrm{I}$, J, and $\mathrm{K}$ were low and ranged between 5.5 and $6.5 \mathrm{mg} \cdot \mathrm{L}^{-1}$. The $\mathrm{pH}$ value of the Tuojiang River was between 7.5 and 8.6, while the minimum value of 7.5 was found at sites $\mathrm{D}$ and $\mathrm{E}$, and the highest value of 8.6 was observed at sites $\mathrm{G}, \mathrm{H}$, and I. COD $\mathrm{Mn}_{\mathrm{n}}$ remained between $2.5 \mathrm{mg} \cdot \mathrm{L}^{-1}$ and $5.5 \mathrm{mg} \cdot \mathrm{L}^{-1}$. The minimum value occurred at site $\mathrm{A}$ and the maximum values at sites $\mathrm{J}$ and $\mathrm{K}$ in the lower reaches. There was a risk of exceeding the $6 \mathrm{mg} \cdot \mathrm{L}^{-1}$ class III limit for $\mathrm{COD}_{\mathrm{Mn}}$. BOD 5 fluctuated between $2.0 \mathrm{mg} \cdot \mathrm{L}^{-1}$ and $5.0 \mathrm{mg} \cdot \mathrm{L}^{-1}$. The spatial pattern of $\mathrm{BOD}_{5}$ was contrary to that of $\mathrm{COD}_{\mathrm{Mn}}$. The monitoring sites $\mathrm{A}, \mathrm{B}$, and $\mathrm{C}$ in the upper reaches had the maximum values of $\mathrm{BOD}_{5}$, while the concentrations in the lower reaches were lower. There was no risk of $\mathrm{BOD}_{5}$ exceeding the class III limit $(<20 \mathrm{ppm})$. The highest concentrations of $\mathrm{NH}_{3}-\mathrm{N}$ were found at sites $\mathrm{E}$ and $\mathrm{F}$ in the middle reaches and exceeded the class III limit of $1.0 \mathrm{ppm}$. The concentrations of $\mathrm{NH}_{3}-\mathrm{N}$ in the lower reaches were lower than those at sites $\mathrm{A}$ and $\mathrm{B}$, which indicated that $\mathrm{NH}_{3}-\mathrm{N}$ discharge was concentrated in the middle and upper reaches of the Tuojiang River. The concentration range of $\mathrm{NH}_{3}-\mathrm{N}$ was $0.25-3.0 \mathrm{mg} \cdot \mathrm{L}^{-1}$. The TP values exceeded the water quality class III limit of $0.2 \mathrm{mg} \cdot \mathrm{L}^{-1}$ at all stations. Maximum values of $0.3 \mathrm{mg} \cdot \mathrm{L}^{-1}$ occurred at sites $\mathrm{B}, \mathrm{C}, \mathrm{D}$, and $\mathrm{E}$ in the middle and upper reaches. The lowest TP concentrations were found at sites $\mathrm{A}, \mathrm{I}$, and $\mathrm{J}$, but also exceeded $0.2 \mathrm{mg} \cdot \mathrm{L}^{-1}$.

According to Figure $4, \mathrm{Cu}$ concentrations were low in the upper reaches $\left(0.005 \mathrm{mg} \cdot \mathrm{L}^{-1}\right)$, and higher concentrations were observed in the middle and lower reaches $\left(0.03 \mathrm{mg} \cdot \mathrm{L}^{-1}\right)$. All these values were far below the concentration limit of $1.0 \mathrm{mg} \cdot \mathrm{L}^{-1}$. The maximum concentration of $\mathrm{Zn}$ was $0.045 \mathrm{mg} \cdot \mathrm{L}^{-1}$, observed at sites C, D, and E. The minimum $\mathrm{Zn}$ concentration of $0.005 \mathrm{mg} \cdot \mathrm{L}^{-1}$ at sites $\mathrm{A}, \mathrm{I}$, and J was far below the $1.0 \mathrm{mg} \cdot \mathrm{L}^{-1}$ class III concentration limit. The maximum concentration of As was found at sites A, B, C, D, and $\mathrm{E}$ in the upper reaches with an average concentration of $0.004 \mathrm{mg} \cdot \mathrm{L}^{-1}$, while the low concentration of As occurred at sites $\mathrm{G}, \mathrm{H}$, and I with an average concentration of $0.0005 \mathrm{mg} \cdot \mathrm{L}^{-1}$. All these values were far below the class III limit of $0.05 \mathrm{ppm}$. Maximum $\mathrm{Hg}$ concentrations were recorded in the upper reaches of the Tuojiang River between sites $\mathrm{A}$ and $\mathrm{E}$. According to Figure 4, there may exist a risk of high $\mathrm{Hg}$ concentrations in the sampling sites in southwest Deyang. The average concentration of $\mathrm{Hg}$ in the upper reaches was $0.00008 \mathrm{mg} \cdot \mathrm{L}^{-1}$, which was close to the limit of $0.0001 \mathrm{mg} \cdot \mathrm{L}^{-1}$, indicating the risk of exceeding this standard. The minimum value of $0.00001 \mathrm{mg} \cdot \mathrm{L}^{-1}$ was found at sites in the middle and lower reaches. According to Figure 4, there was a risk of high Cd concentration throughout the Tuojiang River Basin, especially for the cities of Chengdu and Deyang, with average concentrations of $>0.004 \mathrm{mg} \cdot \mathrm{L}^{-1}$, close to the limit of $0.005 \mathrm{mg} \cdot \mathrm{L}^{-1}$. Cr concentrations were about $0.01 \mathrm{mg} \cdot \mathrm{L}^{-1}$ throughout the Tuojiang River Basin, which was much lower than the limit of $0.05 \mathrm{mg} \cdot \mathrm{L}^{-1}$ for class III water quality. High $\mathrm{Pb}$ concentrations were observed in the middle and lower reaches, sites $\mathrm{F}$ to $\mathrm{K}$, with an average concentration 
of $0.02 \mathrm{mg} \cdot \mathrm{L}^{-1}$. There was a slight risk of exceeding the class III limit in the lower reaches. The minimum value of $0.005 \mathrm{mg} \cdot \mathrm{L}^{-1}$ at sites in the upper reaches was lower than the limit of $0.05 \mathrm{mg} \cdot \mathrm{L}^{-1}$.

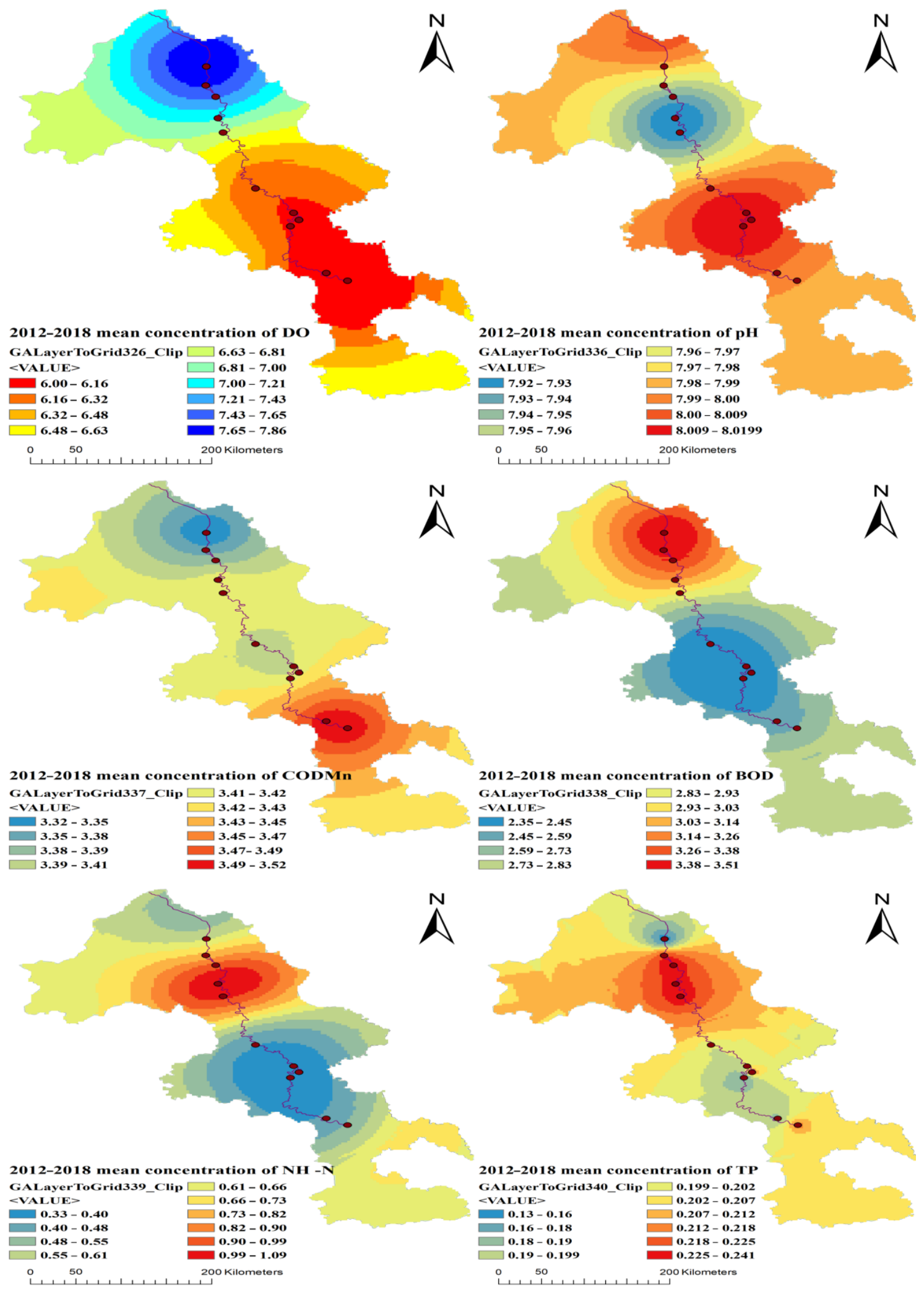

Figure 3. Spatial variation of pollution variables at the 11 monitoring sites from 2012 to 2018. 


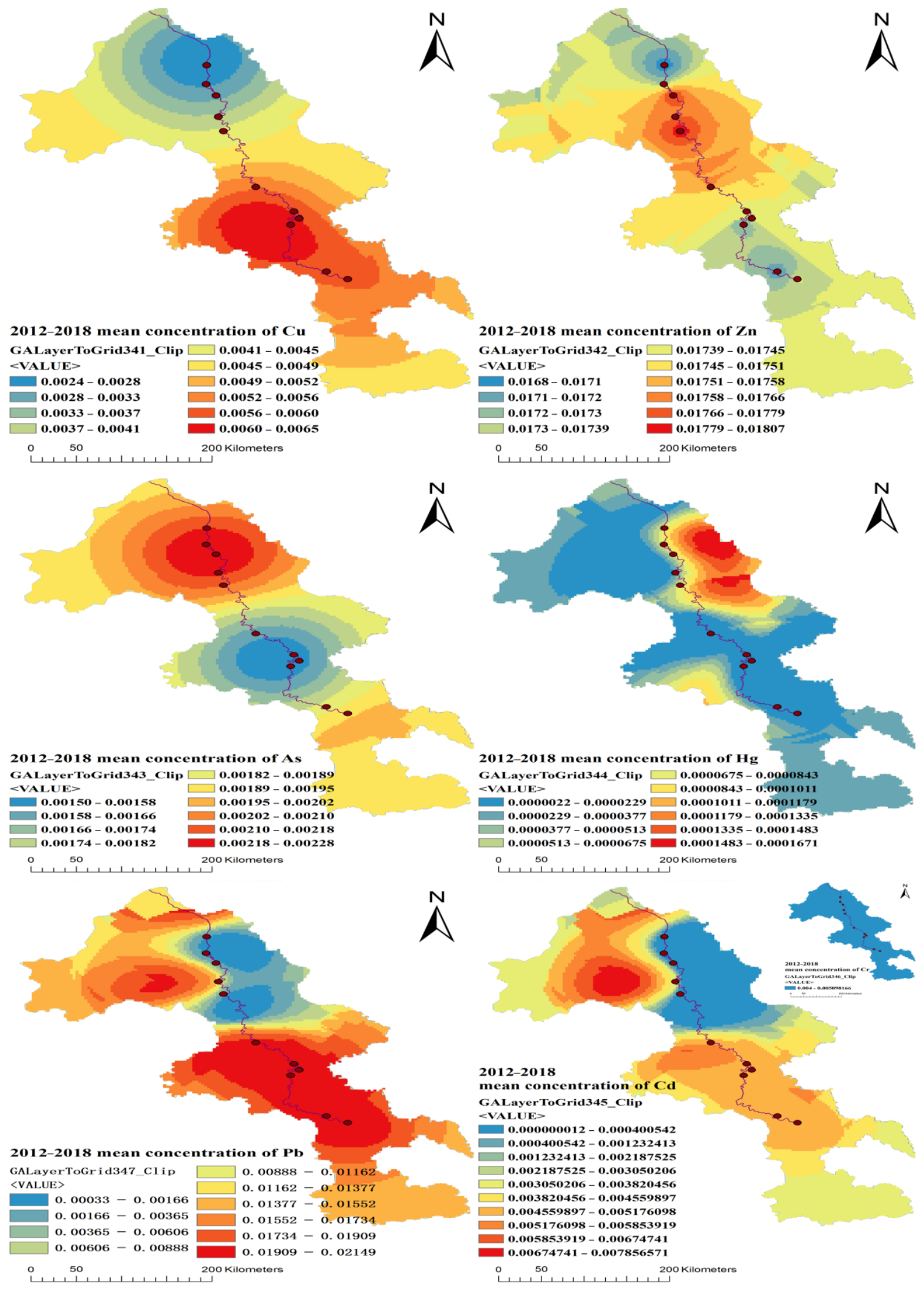

Figure 4. Spatial variation of pollution variables at the 11 monitoring sites from 2012-2018.

In summary, according to the BP-ANN based evaluation and temporal and spatial analysis, there exists the risks of (a) $\mathrm{COD}_{\mathrm{Mn}}$ and $\mathrm{Hg}$ concentrations higher than class III limits in the upper reaches, (b) excessive $\mathrm{Cd}$ concentrations in the entire Tuojiang River 
basin, (c) excessive $\mathrm{Pb}$ in the lower reaches, (d) excessive $\mathrm{NH}_{3}-\mathrm{N}$ in the region between the Deyang and Chengdu sites in the upper reaches, and (e) excessive TP concentrations in the entire Tuojiang River Basin.

\subsubsection{Effects of Industrial Phosphorus Pollution}

Shifang City, located in the upper reaches of Tuojiang River and southwest of Deyang City, is one of the six major phosphate mining sites in China. The phosphorus production accounts for more than $90 \%$ of the gross product of Sichuan Province. The proven reserves in Shifang City amount to 170 million tons, and there are more than 40 phosphorus related enterprises. The annual output of small-scale enterprises is more than 10,000 tons, while the production of large-scale enterprises is about 400,000 tons. The application of phosphate fertilizer and the phosphorus industry may be potential sources of the observed excessive heavy metal concentrations compared with national standards.

Human activities greatly contribute to heavy metals in water and soil. Non-ferrous metal mining, smelting, electroplating, glass manufacturing, the battery industry, printing, and dyeing discharge cadmium, mercury, lead, and other heavy metals. The heavy metal discharge caused by human activities has exceeded natural emissions, and currently, human activities are the main source of heavy metal pollution [40]. Zhang et al. [41] found that the phosphorus industry was the main factor that caused excessive $\mathrm{Cd}$ and $\mathrm{Pb}$ concentrations in the environment. There are many mining areas in the upper reaches of the Tuojiang River, and their effect on water quality should not be underestimated, as shown in Table 10. The phosphorus industry's development in the upper Tuojiang River Basin can also explain the entire basin's excessive TP concentrations.

Table 10. Mineral resources in the upper Tuojiang River Basin.

\begin{tabular}{cc}
\hline Mineral Resource & Reserves of the Resource \\
\hline Natural gas & Proven: $40 \times 10^{8} \mathrm{~m}^{3}$, expected: $1000 \times 10^{8} \mathrm{~m}^{3}$ \\
Coal & $8000 \times 10^{4} \mathrm{t}$ \\
Phosphorite & $3 \times 10^{8} \mathrm{t}$ \\
Limestone & $14 \times 10^{8} \mathrm{t}$ \\
Dolomite & $400 \times 10^{4} \mathrm{t}$ \\
Grit for buildings & Widely distributed in the basin \\
\hline
\end{tabular}

\subsubsection{Sediment Settlement}

The bioavailability and toxicity of heavy metals in water bodies mainly depend on the activity of free heavy metal ions, that is, the fraction of soluble or exchangeable metals in water, rather than the total mass of such heavy metals [42-44]. Most heavy metals in water and soil exist in an insoluble state, and the $\mathrm{pH}$ value controls their solubility. A decrease in the $\mathrm{pH}$ value can lead to the dissolution and release of heavy metals combined with carbonate and hydroxide. It can also increase the release of adsorbed heavy metals. The availability of cadmium in water, soil, or sediment, namely its chemical forms and adsorption-desorption behavior, are regulated mainly by environmental $\mathrm{pH}$. With increases in environmental $\mathrm{pH}$, negative charges in sediment colloids increase, while the competitive effect of $\mathrm{H}^{+}$is weakened. Thus, heavy metals are bound more firmly, mostly in the form of insoluble hydroxide or carbonate and phosphate. As a result, cadmium, mercury, and lead's effectiveness are greatly reduced [45]. The Tuojiang River Basin is about $600 \mathrm{~km}$ long. The widest part of the river is tens of meters, and the depth can reach tens of meters. The river sediment is rich in nutrients. Combined, the concentration variations of heavy metals including cadmium and mercury, and high $\mathrm{pH}$ values cause an effective reduction of heavy metal concentrations due to sedimentation.

\subsubsection{Seasonal Variations}

As mentioned previously, the $\mathrm{pH}$ value and carbonate ligands are among the major factors affecting the speciation of heavy metals in the water body. Figure 5 show the 
variation of $\mathrm{pH}$ in the Tuojiang River between 2012 and 2018 and the total hardness in four seasons from 2015 to 2018.

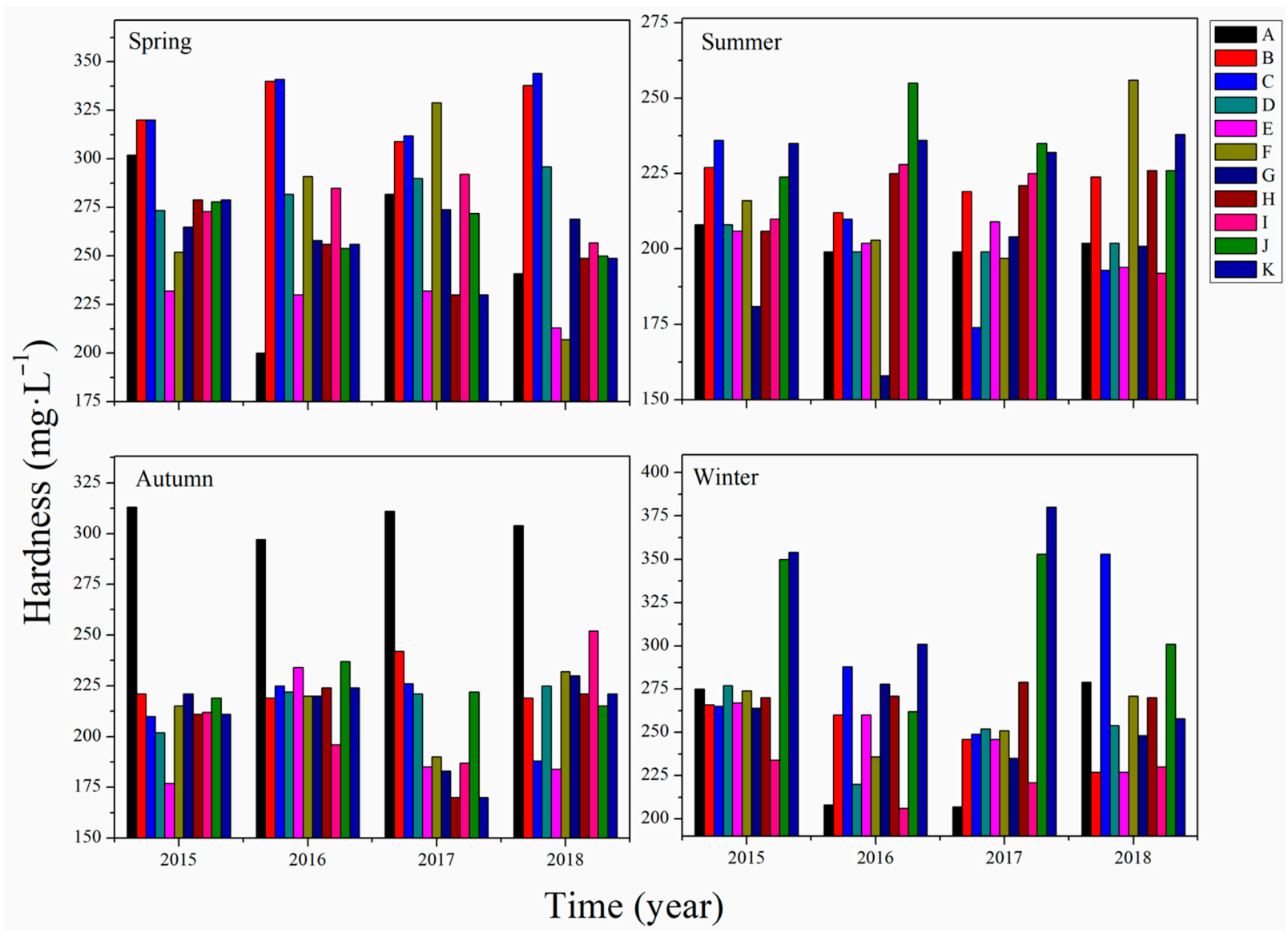

Figure 5. Annual average total hardness of the Tuojiang River.

The $\mathrm{pH}$ values of the six sampling sites in the lower reaches of the Tuojiang River showed little variation among seasons (Figure 6), while the water quality of the five sampling sites in the upper reaches varied seasonally. The $\mathrm{pH}$ values of Shiqiao and Sanhuangmiao were most significantly affected by the seasons. The water quality of Shiqiao and Sanhuangmiao was affected by exogenous pollutants, which is consistent with industrial wastewater and domestic sewage discharge from the cities of Qingjiang to Sanhuangmiao. Total hardness values of the river were similar in spring and winter as well as in summer and autumn (Figure 5). Variations in total water hardness may be affected by water temperature or other contaminants $[46,47]$. Water quality is complex and variable. A variety of inorganic salt ions and heavy metals may combine with ligands and settle, affecting the total hardness of the river water. According to a previous study at Jinghu, the best water quality monitoring section was throughout the whole Tuojiang River Basin. However, in Figure 5, Jinghu's average total hardness was the highest among the five sampling sites in the upper reaches. The unusual trend of total hardness variation in the upper reaches of the Tuojiang River needs further study by sampling the river in the Deyang and Chengdu region as well as further data analysis.

As shown in Figure 7, water hardness is most affected by summer, then by winter, and finally by autumn. In addition, significant changes in the standard deviation of the six upstream monitoring stations may be linked to high urbanization (near Chengdu), so the water quantity varied greatly. The downstream water flows through rural and suburban areas, so the water quality and quantity gradually become stable. 

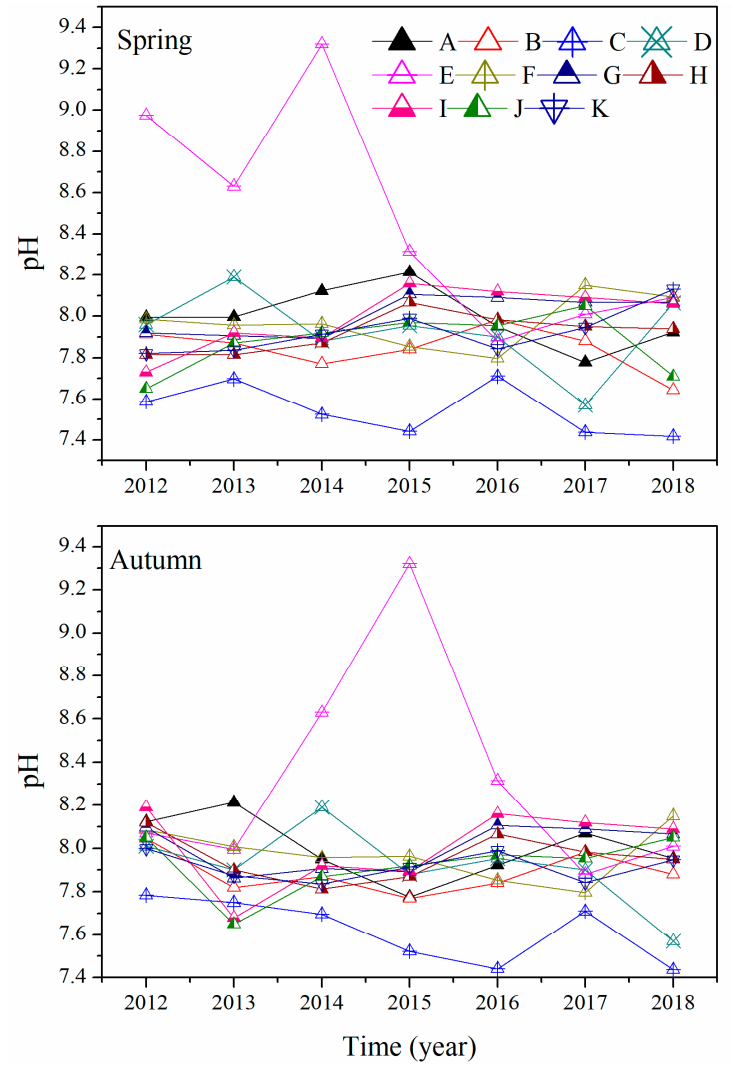
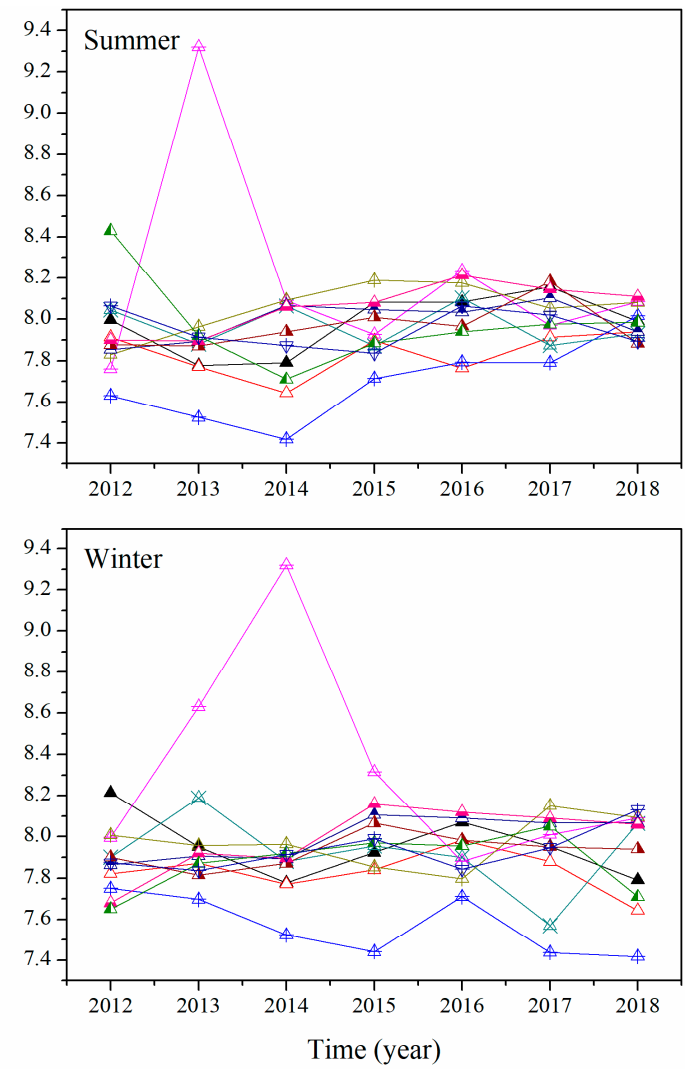

Figure 6. Annual average total $\mathrm{pH}$ of the Tuojiang River.

According to seasonal variation of $\mathrm{pH}$, it is noteworthy to find summer has a different change trend from other seasons. Namely, most mentoring sites have a rising trend in summer. Meanwhile, summer also has the greatest impact on the overall water hardness. At least, we could learn that for water quality control, summer is a special season, which is worth more attention.

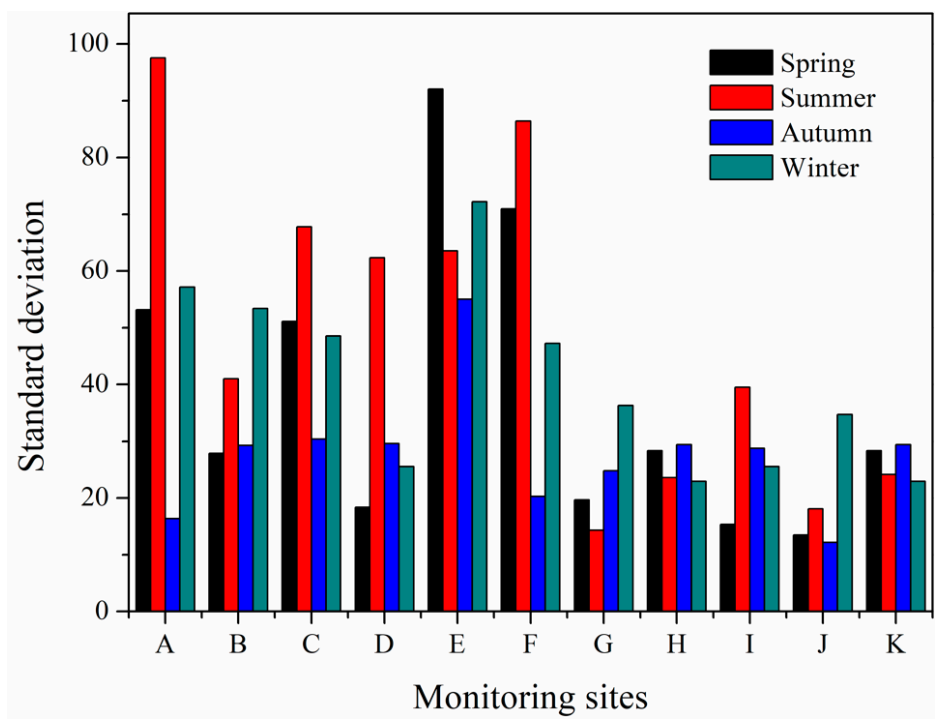

Figure 7. Standard deviation of hardness.

\section{Conclusions}

In this work, 11 national monitoring sites were sampled from 2012 to 2018 in the Tuojiang River Basin in the eastern Chengdu Plain. The BP-ANN method was used to 
determine the comprehensive water quality and analyze the temporal and spatial variations of water quality variables including $\mathrm{DO}, \mathrm{COD}_{\mathrm{Mn}}, \mathrm{BOD}_{5}, \mathrm{NH}_{3}-\mathrm{N}, \mathrm{TP}$, and various heavy metals such as copper, zinc, arsenic, mercury, cadmium, hexavalent chromium, and lead. The temporal and spatial analysis (Figures 3 and 4) suggested pollution and risks of excessive $\mathrm{COD}_{\mathrm{Mn}}, \mathrm{NH}_{3}-\mathrm{N}, \mathrm{TP}$, cadmium, mercury, and lead concentrations compared to the national standards, and network sensitivity analysis revealed that for heavy metals, most change in the water quality was most sensitive to heavy metal content, especially As and $\mathrm{Hg}$.

Combining factors such as industrial phosphorus production and mining in the upper reaches, seasonal water quality variations, speciation of heavy metals in the water and sediment, and potential plant absorption and enrichment, this study explored the temporal and spatial trends of water quality and various analytical indicators. It appears that the phosphorus industry in the upper reaches of the river is the main reason for the excessive contents of TP and heavy metals in the river water. The reduction in the concentrations of pollutants (e.g., mercury and cadmium) in the middle and lower river reaches could be due to self-purification and the enrichment of plants along the Tuojiang River.

For further investigation on water quality, we think that further study should strengthen sampling and monitoring of sediment and aquatic plants to prove our analysis results as well as pay special attention to the concentration of cadmium, mercury, and lead in the sediment. Furthermore, how $\mathrm{pH}$ and hardness impact on metal content in water is worth more attention. To control the water pollution of the Tuojiang River, concerned agencies should plant a large number of green plants along this river and reduce upstream industrial emissions.

Potential limitations of this study are due to the fact that some data (such as those from 2012) were obtained very early, and there are inevitably minor measurement errors. In this study, water quality analyses from 2012 to 2018 provided specific data and method references for future studies of the whole basin or parts of the Tuojiang River Basin. This study may also offer new perspectives to investigations in the broader area of water quality.

Author Contributions: Conceptualization, Z.Z.; Funding acquisition, Z.Z.; Investigation, Z.Z. and Z.W.; Methodology, W.-G.L.; Software, W.-G.L.; Supervision, F.-C.Y.; Writing-original draft, W.-G.L. All authors have read and agreed to the published version of the manuscript.

Funding: This study was supported by the National Natural Science Foundation of China (41402248); the National Key R\&D Program of China (2019YFC1803500, 2019YFC1803504); the Key Research and Development Projects of Sichuan Science and Technology Department (No. 2018SZ0298); the Scientific Research Project of Sichuan Education Department (No. 16ZB0150); the Nuclear Facility Decommissioning and Radioactive Waste Treatment Research Project of the State Administration of Science, Technology, and Industry of National Defense (No. 1521 [2018] of the Second Division of Science and Technology); the Longshan Academic Research Talent Support Program of Southwest University of Science and Technology (No. 18LZX309, 17LZX613, 18LZX638, and 18LZXT03); and the Southwest University of Science and Technology Natural Science Foundation (No. 18zx7125).

Institutional Review Board Statement: Not applicable.

Informed Consent Statement: Not applicable.

Data Availability Statement: Not applicable.

Conflicts of Interest: The authors declare no conflict of interest. 


\section{References}

1. Otero, I.; Kallis, G.; Aguilar, R.; Ruiz, V. Water scarcity, social power and the production of an elite suburb: The political ecology of water in Matadepera, Catalonia. Ecol. Econ. 2011, 70, 1297-1308. [CrossRef]

2. Bogardi, J.J.; Dudgeon, D.; Lawford, R.; Flinkerbusch, E.; Meyn, A.; Pahl-Wostl, C.; Viehlhauer, K.; Vörösmarty, C. Water security for a planet under pressure: Interconnected challenges of a changing world call for sustainable solutions. Curr. Opin. Environ. Sustain. 2012, 4, 35-43. [CrossRef]

3. Trenberth, K.E.; Dai, A.; van der Schrier, G.; Jones, P.D.; Barichivich, J.; Briffa, K.R.; Sheffield, J. Global warming and changes in drought. Nat. Clim. Chang. 2014, 4, 17-22. [CrossRef]

4. UNESCO. The United Nations World Water Development Report 3: Water in a Changing World; UNESCO: Paris, France; Berghahn Books: New York, NY, USA, 2009.

5. Schwarzenbach, R.P.; Escher, B.I.; Fenner, K.; Hofstetter, T.B.; Johnson, C.A.; Von Gunten, U.; Wehrli, B. The Challenge of Micropollutants in Aquatic Systems. Science 2006, 313, 1072-1077. [CrossRef]

6. Fenwick, A. Waterborne Infectious Diseases-Could They Be Consigned to History? Science 2006, 313, 1077-1081. [CrossRef]

7. Jorgenson, A.K. Political-economic integration, industrial pollution and human health: A panel study of less-developed countries, 1980-2000. Int. Soc. 2009, 24, 115-143. [CrossRef]

8. Gruber, N.; Galloway, J.N. An Earth-system perspective of the global nitrogen cycle. Nature 2008, 451, 293-296. [CrossRef]

9. Filippelli, G.M. The Global Phosphorus Cycle: Past, Present, and Future. Elements 2008, 4, 89-95. [CrossRef]

10. Zhou, G.; Wang, Q.; Zhang, J.; Li, Q.; Wang, Y.; Wang, M.; Huang, X. Distribution and characteristics of microplastics in urban waters of seven cities in the Tuojiang River basin, China. Environ. Res. 2020, 189, 109893. [CrossRef]

11. Department of Ecology and Environment of Sichuan Province. Sichuan Ecology and Environment Statements. 2019. Available online: http:/ / sthjt.sc.gov.cn/sthjt/c104157/2020/6/4/ef7b43728c6945ce9e15bc5c6f011f30.shtml (accessed on 4 June 2020).

12. Hua, L.; Sui, H.; Wang, J.; Shao, Y. Investigation and Evaluation of Soil Heavy METALS Pollution Supported by DTM and 3D Visualization. In Proceedings of the MIPPR 2005: Geospatial Information, Data Mining, and Applications, Wuhan, China, 31 October-2 November 2005; Volume 6045, p. 60452S.

13. Ji, X.; Dahlgren, R.A.; Zhang, M. Comparison of seven water quality assessment methods for the characterization and management of highly impaired river systems. Environ. Monit. Assess. 2016, 188, 15. [CrossRef]

14. Wang, Y.Y.; Zhao, R.B.; Zhao, Y.W.; Sun, Y. Research on the Application of Fuzzy comprehensive Evaluation method in lake Water Quality Evaluation. Jiangsu Agric. Sci. 2010, 1, 326-328. (In Chinese)

15. He, Y.J.; Wang, N.; Wang, G.L. Fuzzy Comprehensive Evaluation on North-China Groundwater Quality. Adv. Mater. Res. 2012, 613, 2729-2733. [CrossRef]

16. Qiao, J.-J.; Zhen, X.-W.; Zhang, Y.-R. The Application of Fuzzy Comprehensive Evaluation on the Water Quality of Changjiang River. In Proceedings of the 2008 International Conference on Machine Learning and Cybernetics, Kunming, China, 12-15 July 2008; Volume 3, pp. 1467-1473.

17. Li, Z.; Hao, J.; Hu, Z.; Luo, D. Applying Fuzzy Comprehensive Evaluation on the Water Environmental Quality Assessment of Heshan Stream Water Source. In Proceedings of the 2013 International Conference on Information Technology and Applications, Chengdu, China, 16-17 November 2013; pp. 296-299.

18. Fei, Q.; Xubo, H.; Yong, L.; Maoxi, X.; Cheng, L.; Tao, F. Evaluation of groundwater quality in chenghe mining area based on fuzzy comprehensive evaluation. Groundwater 2020, 42, 21-25. (In Chinese)

19. Liu, D.; Qi, X.; Fu, Q.; Li, M.; Zhu, W.; Zhang, L.; Faiz, M.A.; Khan, M.I.; Li, T.; Cui, S. A resilience evaluation method for a combined regional agricultural water and soil resource system based on Weighted Mahalanobis distance and a Gray-TOPSIS model. J. Clean. Prod. 2019, 229, 667-679. [CrossRef]

20. Sutadian, A.D.; Muttil, N.; Yilmaz, A.G.; Perera, B. Using the Analytic Hierarchy Process to identify parameter weights for developing a water quality index. Ecol. Indic. 2017, 75, 220-233. [CrossRef]

21. Zhao, R.; He, H.; Zhang, N. Regional Water Footprint Assessment: A Case Studyof Leshan City. Sustain. Dev. 2015, 7, 16532-16547. [CrossRef]

22. Gazzaz, N.M.; Yusoff, M.K.; Aris, A.Z.; Juahir, H.; Ramli, M.F. Artificial neural network modeling of the water quality index for Kinta River (Malaysia) using water quality variables as predictors. Mar. Pollut. Bull. 2012, 64, 2409-2420. [CrossRef]

23. Velasquez, M.; Hester, P.T. An analysis of multi-criteria decision making methods. Int. J. Oper. Res. 2013, $10,56-66$.

24. Raman, H.; Sunilkumar, N. Multivariate modelling of water resources time series using artificial neural networks. Hydrol. Sci. J. 1995, 40, 145-163. [CrossRef]

25. Adamowski, J.; Chan, H.F.; Prasher, S.O.; Ozga-Zielinski, B.; Sliusarieva, A. Comparison of multiple linear and nonlinear regression, autoregressive integrated moving average, artificial neural network, and wavelet artificial neural network methods for urban water demand forecasting in Montreal, Canada. Water Resour. Res. 2012, 48, W01528. [CrossRef]

26. Karsoliya, S. Approximating number of hidden layer neurons in multiple hidden layer BPNN architecture. Int. J. Eng. Trends Technol. 2012, 3, 714-717.

27. Xu, S.; Chen, L. A Novel Approach for Determining the Optimal Number of Hidden Layer Neurons for FNN's and Its Application in Data Mining. In Proceedings of the 5th International Conference on Information Technology and Applications (ICITA 2008), Cairns, Australia, 23-26 June 2008. 
28. Vujicic, T.; Matijevic, T.; Ljucovic, J.; Balota, A.; Ševarac, Z. Comparative Analysis of Methods for Determining Number of Hidden Neurons in Artificial Neural Network. In Proceedings of the Central European Conference on Information and Intelligent Systems, Varaždin, Croatia, 21-23 September 2016.

29. Li, J.Y.; Chow, T.W.S.; Yu, Y.L. The Estimation Theory and Optimization Algorithm for the Number of Hidden Units in the Higher-Order Feedforward Neural Network. In Proceedings of the ICNN'95-International Conference on Neural Networks, Perth, Australia, 27 November-1 December 1995; Volume 3, pp. 1229-1233.

30. Tamura, S.; Tateishi, M. Capabilities of a four-layered feedforward neural network: Four layers versus three. IEEE Trans. Neural Netw. 1997, 8, 251-255. [CrossRef] [PubMed]

31. Shibata, K.; Ikeda, Y. Effect of Number of Hidden Neurons on Learning in Large-Scale Layered Neural Network. In Proceedings of the 2009 ICCAS-SICE, Fukuoka, Japan, 18-21 August 2009; pp. 5008-5013.

32. Hunter, D.; Yu, H.; Pukish, M.S., III; Kolbusz, J.; Wilamowski, B.M. Selection of proper neural network sizes and architectures-A comparative study. IEEE Trans. Ind. Inform. 2012, 8, 228-240. [CrossRef]

33. Sheela, K.G.; Deepa, S.N. Review on methods to fix number of hidden neurons in neural networks. Math. Probl. Eng. 2013, 2013. [CrossRef]

34. Heaton, J. Introduction to Neural Networks with Java; Heaton Research, Inc.: Washington, DC, USA, 2008.

35. Wang, F.Y.; Tang, Y.F. Application of artificial neural network in water Quality evaluation of Daqing River. Northeast Water Conserv. Hydropower 2019, 25, 2. (In Chinese)

36. Zhao, J.; Zhang, Z.Y.; Xie, Z.Y.; Huang, J.L.; Huang, Z.Y. Water quality modeling for water works in the Minjiang River estuary based on BP neural network model. Environ. Sci. Technol. 2020, 43, 198-203. (In Chinese)

37. Ghiassi, M.; David, K.Z.; Saidane, H. Urban Water Demand Forecasting with a Dynamic Artificial Neural Network Model. J. Water Resour. Plan. Manag. Mar. 2008, 2, 134. [CrossRef]

38. Alvisi, S.; Mascellani, G.; Franchini, M.; Bárdossy, A. Water level forecasting through fuzzy logic and artificial neural network approaches. Hydrol. Earth Syst. Sci. Discussions Eur. Geosci. Union 2006, 10, 1-17. [CrossRef]

39. Firat, M.; Yurdusev, M.A.; Turan, M.E. Evaluation of Artificial Neural Network Techniques for Municipal Water Consumption Modeling. Water Resour. Manag. 2009, 23, 617-632. [CrossRef]

40. Nriagu, J.O.; Pacyna, J.M. Quantitative assessment of worldwide contamination of air, water and soils by trace metals. Nature 1988, 333, 134-139. [CrossRef]

41. Zhang, M.K.; Ke, Z.X. Heavy metals, phosphorus and some other elements in urban soils of Hangzhou city, China. Pedosphere 2004, 14, 177-185.

42. Sauvé, S.; Cook, N.; Hendershot, W.H.; McBride, M.B. Linking plant tissue concentrations and soil copper pools in urban contaminated soils. Environ. Pollut. 1996, 94, 153-157. [CrossRef]

43. Sauvé, S.; Dumestre, A.; McBride, M.; Hendershot, W. Derivation of soil quality criteria using predicted chemical speciation of $\mathrm{Pb} 2+$ and $\mathrm{Cu} 2+$. Environ. Toxicol. Chem. 2010, 17, 1481-1489. [CrossRef]

44. Mcbride, M.B. Cadmium uptake by crops estimated from soil total Cd and pH. Soil Sci. 2002, 167, 62-67. [CrossRef]

45. Singh, B.R.; Myhr, K. Cadmium uptake by barley as affected by Cd sources and pH levels. Geoderma 1998, 84, 185-194. [CrossRef]

46. Martins, R.J.; Pardo, R.; Boaventura, R.A. Cadmium(II) and zinc(II) adsorption by the aquatic moss Fontinalis antipyretica: Effect of temperature, $\mathrm{pH}$ and water hardness. Water Res. 2004, 38, 693-699. [CrossRef]

47. Amor, M.B.; Zgolli, D.; Tlili, M.M.; Manzola, A.S. Influence of water hardness, substrate nature and temperature on heterogeneous calcium carbonate nucleation. Desalination 2004, 166, 79-84. [CrossRef] 